\title{
Complex genomic and phenotypic characterization of the related species Staphylococcus carnosus and Staphylococcus piscifermentans
}

\author{
Roman Pantůček, ${ }^{1}$ Ivo Sedláček, ${ }^{2}$ Jiří Doškař ${ }^{1}$ and Stanislav Rosypal ${ }^{1}$
}

Author for correspondence: Stanislav Rosypal. Tel: + 420541129549 . Fax: +420541211214.
e-mail: rosypal $(\alpha$ sci.muni.cz

1 Department of Genetics and Molecular Biology, Faculty of Science, Masaryk University, Kotlářská 2, 61137 Brno, Czech Republic

2 Czech Collection of Microorganisms, Faculty of Science, Masaryk University, Trrdého 14, 60200 Brno, Czech Republic

\begin{abstract}
On the basis of numerical analysis of 100 phenotypic features, the strains of two species, Staphylococcus carnosus and Staphylococcus piscifermentans, were differentiated into two separate phenons corresponding with the macrorestriction patterns of their genomic DNA, as well as with the results of ribotyping and PCR amplification of enterobacterial repetitive intergenic consensus sequences. One of the S. carnosus strains, the F-2 strain, was shown to be marginal, exhibiting the lowest genomic and phenotypic similarity to the S. carnosus type strain DSM 20501'. Two of the strains studied (strains $S$. carnosus SK 06 and S. piscifermentans SK 05) were phenotypically convergent, forming a separate phenon. They were phenotypically similar, even though the genomic DNA of one of them was homologous with that of the $S$. carnosus type strain, whereas that of the other was homologous with the genomic DNA of the S. piscifermentans type strain. In such cases, fingerprinting methods (particularly macrorestriction analysis and ribotyping) served as important correctives, as they allow phenotypically convergent strains to be distinguished on the basis of their genomic profiles. The results of this paper support the proposal for the new species Staphylococcus condimenti as well as the new subspecies Staphylococcus carnosus subsp. utilis.
\end{abstract}

Keywords: Staphylococcus carnosus, Staphylococcus piscifermentans, PFGE, ribotyping, ERIC-PCR

\section{INTRODUCTION}

Strains of Staphylococcus carnosus were previously incorrectly classified in the genus Micrococcus (Niinivaara \& Pohja, 1956) and later, tentatively, as belonging to the species Staphylococcus simulans (Fischer \& Schleifer, 1980). On the basis of DNADNA hybridization relationships, biochemical reactions and cell wall composition, they were defined as a new species, S. carnosus (Schleifer \& Fischer, 1982). The species Staphylococcus piscifermentans was defined by Tanasupawat et al. (1992) in strains isolated from fermented fish and soy sauce mash in Thailand. Both the species are used alone or in combination with

Abbreviations: ERIC-PCR, PCR amplification of enterobacterial repetitive intergenic consensus sequences; $S_{j}$, Jaccard's similarity coefficient; $S_{S M}$, simple matching similarity coefficient; $T A E$, Tris/acetate electrophoresis buffer; UPGMA, unweighted pair group method with averages. the other bacterial strains (Staphylococcus xylosus and strains of the genus Pediococcus and Lactobacillus) as starter cultures in food technology (Nychas \& Arkoudelos, 1990; Hammes et al., 1995; Hartmann et al., 1995).

As an apathogenic organism, S. carnosus is also widely used as a Gram-positive recipient strain for molecular cloning (Götz, 1990; Halfmann et al., 1993; Ayora \& Götz, 1994; Connolly et al., 1994; Wieland et al., 1994; Heilmann et al., 1996; Neubauer \& Götz, 1996), as well as for the production of heterologous proteins (Demleitner \& Götz, 1994; Pschorr et al., 1994; Samuelson et al., 1995; Strauss \& Götz, 1996; Robert et al., 1996; Thumm \& Götz, 1997; Liljeqvist et al., 1997). Different methods for the transformation of $S$. carnosus (Götz et al., 1983; Götz \& Schumacher, 1987; Augustin \& Götz, 1990) and suitable cloning vectors for recipient $S$. carnosus strains (Keller et al., 1983; Kreutz \& Götz, 1984; Augustin et al., 1992; 
Rosenstein et al., 1992; Wieland et al., 1995; Brückner \& Götz, 1996; Brückner, 1997) were developed. Recently, the physical and genetic map of the $S$. carnosus genome was constructed (Wagner et al., 1998) and several genes were characterized and sequenced (Kohlbrecher et al., 1992; Witke \& Götz, 1993, 1995; Meens et al., 1994; Christiansen \& Hengstenberg, 1996; Fast et al., 1996).

According to Tanasupawat et al. (1991, 1992), the strains classified as species $S$. piscifermentans and $S$. carnosus are similar to each other in their determinative phenotypic characteristics. Therefore, these characteristics have only relative value for separating these two species. Furthermore, there are some differences between the characteristics of $S$. carnosus given in Bergey's Manual of Systematic Bacteriology and the characteristics found by Tanasupawat et al. (1992). On the other hand, in spite of the similarity in phenotypic characteristics, the species $S$. piscifermentans and $S$. carnosus could be differentiated from each other on the basis of DNA relatedness. The DNA homology values between $S$. piscifermentans and $S$. carnosus type strains were estimated to be $43 \%$ and those between $S$. piscifermentans and the other staphylococcal species were less than $25 \%$ (Tanasupawat et al., 1992).

It follows from these data that a strategy for differentiation of $S$. carnosus from $S$. piscifermentans has not been complete up to the present. Since $S$. carnosus is used industrially as a starter culture, the boundary between the two species should be defined on the basis of a description including more phenotypic features in correlation with their genomic relatedness. We concentrated therefore on the following points: (i) to show whether these two species are phenotypically distinguishable when using a greater number of phenotypic features subjected to numerical analysis according to Sneath \& Sokal (1973); (ii) to complement DNA-DNA hybridization analysis of genetic relatedness made by Tanasupawat et al. (1992) with DNA fingerprinting techniques [PFGE of macrorestriction fragments of genomic DNA, ribotyping and ERICPCR (PCR amplification of enterobacterial repetitive intergenic consensus sequences); so far these techniques have not been used in distinguishing these two species]; (iii) to show to what measure phenotypic and genomic characteristics correspond with each other; and (iv) to correlate results obtained in this paper with the proposal (Probst et al., 1998) for the new species Staphylococcus condimenti including the strains previously identified as $S$. carnosus and the new subspecies Staphylococcus carnosus subsp. utilis.

\section{METHODS}

Bacterial strains. The bacterial strains (Table 1) were obtained as follows: those labelled as CCM were from the Czech Collection of Microorganisms (Brno, Czech Republic); those designated SK, F-2, M3 and TM 300 were from Professor F. Götz (Universität Tübingen, Tübingen, Germany); and the type strain S. carnosus DSM 20501 ${ }^{\mathrm{T}}$ was obtained from the German Collection of Microorganisms and Cell Cultures (Braunschweig, Germany). The strain Mediph 2 was obtained from Medipharm CZ.

Biotyping. The tested cultures were examined for the following characters by key tube or plate tests as previously described (Barrow \& Feltham, 1993; Hébert et al., 1988; Kloos \& Bannerman, 1994, 1995; Kloos \& Schleifer, 1975): colony morphology and pigment; catalase activity; tube coagulase activity; clumping factor (Murex Diagnostica); growth in $15 \% \mathrm{NaCl}$; anaerobic growth in a thioglycollate medium; growth at 15 and $45^{\circ} \mathrm{C}$; novobiocin $(1.6 \mu \mathrm{g})$ and furazolidone $(100 \mu \mathrm{g})$ resistance; hydrolysis of DNA, Tween 80 , gelatin, starch, casein and tyrosine; antibacterial sensitivity testing (bioMérieux discs: tetracycline $30 \mu \mathrm{g}$, oxacillin $1 \mu \mathrm{g}$, gentamicin $10 \mu \mathrm{g}$, imipenem $10 \mu \mathrm{g}$, erythromycin $15 \mu \mathrm{g}$, chloramphenicol $30 \mu \mathrm{g}$, piperacillin $100 \mu \mathrm{g}$, penicillin $\mathrm{G} 10 \mathrm{U}$ ). Additional biochemical profile data were obtained by using the ID32 Staph system and API 50CH and API ZYM systems (bioMérieux). The ID32 Staph system is based on detection of the activities of 26 tests of staphylococcal identification. The API 50CH test is strip-based and allows the study of bacterial carbohydrate metabolism; results are indicated by changes in the colour of the $\mathrm{pH}$ indicator in wells. The API ZYM system is a semiquantitative micromethod designed for the detection of 19 enzymic activities. The sensitivity to polyvalent bacteriophages of the Twort species was estimated as described previously (Pantůček et al., 1998).

Genomic DNA preparation and PFGE. DNA isolation for PFGE was performed according to the methods of Pantůček et al. (1996). For restriction enzyme cleavage, SmaI (Boehringer Mannheim) and ApaI (Promega) were used. Cleavage was performed with $8 \mathrm{U}$ enzyme (for $1 \times 1 \times 5 \mathrm{~mm}$ agarose blocks) overnight. PFGE was performed with the CHEF-MAPPER system (Bio-Rad) in $1.2 \%(\mathrm{w} / \mathrm{v})$ agarose gels (Qualex Gold Agarose; Angewandte Gentechnologie Systeme) at $14^{\circ} \mathrm{C}$ in a $1 \times$ Tris/acetate electrophoresis buffer (TAE buffer, $0.04 \mathrm{M}$ Tris/acetate, 0.001 M EDTA, $\mathrm{pH} 8 \cdot 2$ ). A constant voltage $6 \mathrm{~V} \mathrm{~cm}^{-1}$ was applied with an increasing pulse time of $1-45 \mathrm{~s}$ over a period of $34 \mathrm{~h}$. As size markers, concatemers of pBR328 (5 kb ladder; Bio-Rad) and concatemers of bacteriophage $\lambda \mathrm{cI} 857 \mathrm{Sam} 7$ (Bio-Rad) were used. The gels were stained in ethidium bromide $(0.5 \mu \mathrm{g}$ $\mathrm{ml}^{-1}$ in $1 \times$ TAE buffer), destained in water and photographed under UV illumination $(302 \mathrm{~nm})$.

DNA isolation for ribotyping and PCR. Whole-cell DNA was prepared from overnight cultures in a $20 \mathrm{ml}$ brain-heart infusion broth (Oxoid) at $37^{\circ} \mathrm{C}$. Bacterial cells were harvested by centrifugation for $15 \mathrm{~min}$ at $8000 \mathrm{~g}$ at $4{ }^{\circ} \mathrm{C}$, washed in $10 \mathrm{ml} \mathrm{NaCl}$-buffer $(50 \mathrm{mM}$ Tris $/ \mathrm{HCl} \mathrm{pH} 8.0$, $2.5 \mathrm{M} \mathrm{NaCl}, 50 \mathrm{mM}$ EDTA), resuspended in $3 \mathrm{ml}$ standard PBS buffer $\left(0.145 \mathrm{M} \mathrm{NaCl}, 0.01 \mathrm{M} \mathrm{Na} \mathrm{HPO}_{4}, 0.0017 \mathrm{M}\right.$ $\mathrm{KH}_{2} \mathrm{PO}_{4}, \mathrm{pH} \mathrm{7.4)}$ containing lysostaphin $\left(5 \mu \mathrm{g} \mathrm{ml}^{-1}\right.$; Sigma), lysozyme $\left(0.2 \mathrm{mg} \mathrm{ml}^{-1}\right)$ and RNase $\left(10 \mu \mathrm{g} \mathrm{ml}^{-1}\right)$ and the mixture was then incubated for $30 \mathrm{~min}$ at $37^{\circ} \mathrm{C}$. Lysis was completed by adding $3 \mathrm{ml} 1 \%$ (w/v) SDS solution and incubating for $10 \mathrm{~min}$ at $37^{\circ} \mathrm{C}$. The samples were then treated with proteinase $\mathrm{K}$ (Merck), added to a final concentration $200 \mu \mathrm{g} \mathrm{ml}^{-1}$, and incubated at $55^{\circ} \mathrm{C}$ for $60 \mathrm{~min}$. Purification of DNA was performed by phenol/ chloroform/isoamyl alcohol (25:24:1, by vol.) and chloroform extractions and ethanol precipitation according to Maniatis et al. (1982).

Ribotyping. EcoRI (Boehringer Mannheim) digested DNAs $(10 \mu \mathrm{g})$ were resolved by horizontal slab gel electrophoresis performed in $1.0 \%(\mathrm{w} / \mathrm{v})$ agarose gels in $1 \times$ TAE buffer at 
Table 1. S. carnosus and S. piscifermentans strains under study

\begin{tabular}{|c|c|c|}
\hline Strain & Other designation & Reference \\
\hline S. carnosus DSM $20501^{\mathrm{T}}$ & Strain no. 361 & Schleifer \& Fischer (1982) \\
\hline S. carnosus CCM 3885 & Strain no. 51 & Schleifer \& Fischer (1982) \\
\hline S. carnosus CCM 3886 & Strain no. 91 & Schleifer \& Fischer (1982) \\
\hline S. carnosus CCM 4579 & Isolated from dry sausage & \\
\hline S. carnosus Mediph 2 & Starter culture & \\
\hline S. carnosus TM 300 & Strain no. 311 & Schleifer \& Fischer (1982) \\
\hline S. carnosus M3 & Derived from TM 300 & \\
\hline S. carnosus SK 06 & S. carnosus subsp. utilis SK 06 & $\begin{array}{l}\text { Tanasupawat et al. (1991); } \\
\text { Probst et al. (1998) }\end{array}$ \\
\hline S. carnosus F-2 & $\begin{array}{l}\text { 'Tetracoccus soyae' } \mathrm{F}-2, \\
\text { Staphylococcus condimenti } \mathrm{F}-2^{\mathrm{T}}\end{array}$ & $\begin{array}{l}\text { Tanasupawat et al. (1991); } \\
\text { Probst et al. (1998) }\end{array}$ \\
\hline S. piscifermentans CCM $4345^{\mathrm{T}}$ & Strain SK 03 & Tanasupawat et al. (1992) \\
\hline S. piscifermentans CCM 4346 & Strain SK 14 & Tanasupawat et al. (1992) \\
\hline S. piscifermentans CCM 4347 & Strain SK 16 & Tanasupawat et al. (1992) \\
\hline S. piscifermentans SK 02 & & Tanasupawat et al. (1992) \\
\hline S. piscifermentans SK 05 & & Tanasupawat et al. (1992) \\
\hline
\end{tabular}

$0.8 \mathrm{~V} \mathrm{~cm}^{-1}$ for $16 \mathrm{~h}$ at room temperature. DNA fragments were transferred to nylon membranes (Boehringer Mannheim) by a capillary Southern blot procedure using $20 \times \operatorname{SSC}(3 \mathrm{M} \mathrm{NaCl}, 0 \cdot 3 \mathrm{M}$ sodium citrate, $\mathrm{pH} \mathrm{7 \cdot 0})$. Labelling of DNA probes from $16 \mathrm{~S}$ and $24 \mathrm{~S}$ rRNA of Escherichia coli (Boehringer Mannheim) with digoxigenin11-dUTP (Boehringer Mannheim), hybridization and immunological detection (DIG DNA Labelling and Detection kit; Boehringer Mannheim) were performed as described by Bangsborg et al. (1995). DIG-labelled molecular mass markers II and VII (Boehringer Mannheim) were used as size standards.

PCR amplification of bacterial DNA. The primers ERIC 1R and ERIC 2 described by Versalovic et al. (1991) were synthesized on the Expedite 8909 Nucleic Acid Synthesis system (PerSeptive Biosystems) and used without further purification. The reaction mixtures $(50 \mu \mathrm{l})$ consisted of $10 \mathrm{mM}$ Tris/ $/ \mathrm{HCl} \mathrm{pH} 9 \cdot 0,50 \mathrm{mM} \mathrm{KCl}, 2.5 \mathrm{mM} \mathrm{MgCl}, 0.1 \%$ Triton X-100 and $200 \mu \mathrm{M}$ each of dNTPs. To each reaction, $1 \mu \mathrm{l} 50 \mu \mathrm{M}$ primer stock, $1 \mathrm{U}$ Taq DNA polymerase (Promega) and template DNA (50 ng) in a $1 \mu$ l volume were added. PCR was performed using 40 cycles of amplification consisting of denaturation $\left(1 \mathrm{~min}, 94^{\circ} \mathrm{C}\right)$, annealing $\left(1.5 \mathrm{~min}, 35^{\circ} \mathrm{C}\right)$ and DNA chain extension $\left(2 \mathrm{~min}, 74^{\circ} \mathrm{C}\right)$ in a DNA thermal cycler (model GENE E; Techne).

After amplification, $20 \mu \mathrm{l}$ mixture was mixed with $5 \mu \mathrm{l}$ loading buffer $(10 \%$, v/v Ficoll $400,10 \mathrm{mM}$ Tris $/ \mathrm{HCl}$ $\mathrm{pH} 7.5,50 \mathrm{mM}$ EDTA and $0.25 \%$ bromophenol blue) and electrophoresed in a $2.0 \%(\mathrm{w} / \mathrm{v})$ agarose gel (Qualex Gold Agarose) for $4 \mathrm{~h}$ at $5 \mathrm{~V} \mathrm{~cm}^{-1}$ in $1 \times \mathrm{TAE}$ buffer. Molecular mass marker VI (Boehringer Mannheim) was used as a size standard. The gels were stained in ethidium bromide $(0.5 \mu \mathrm{g}$ $\mathrm{ml}^{-1}$ ) and photographed under UV illumination $(302 \mathrm{~nm})$.

Numerical analysis of phenotypic tests. The results of phenotypic tests were examined by numerical analysis according to Sneath \& Sokal (1973) using SPSS 7.5 for Windows. Both the simple matching similarity coefficient $\left(S_{\mathrm{SM}}\right)$ and Jaccard's similarity coefficient $\left(S_{\mathrm{J}}\right)$ were calculated. The dendrograms constructed on the basis of these coefficients by the UPGMA (unweighted pair group method with averages) algorithm exhibited stable clusters. The $S_{J}$ coefficient, which ignores negative matches and is suitable for weakly reacting organisms (Logan, 1994), was chosen for final presentation.

Numerical analysis of band patterns. Photographs of gels were scanned with the S-12 Scanner (UMAX Data Systems) equipped with Adobe Photoshop 4.0. Digitized gel images were analysed using GELCOMPAR 4.1 software (Applied Maths BVBA). Intra-gel inconsistencies and variations in electrophoresis conditions were corrected by computer alignment of the size standards added at regular intervals in separate tracks.

Macrorestriction patterns and ribotype patterns of DNAs isolated from individual strains were compared quantitatively by using the formula proposed by Upholt (1977) and Nei \& Li (1979):

$F_{x y}=2 n_{x y} /\left(n_{x}+n_{y}\right)$,

in which $F_{x y}$ is the proportion of restriction fragments that are common to the strains compared (identical with the Dice similarity coefficient, $\left.S_{\mathrm{D}}\right) ; n_{x}$ and $n_{y}$ are the total number of restriction fragments observed in strains $\mathrm{x}$ and $\mathrm{y}$, respectively; and $n_{x y}$ is the number of restriction fragments shared by both strains $\mathrm{x}$ and $\mathrm{y}$.

The levels of similarity between different PCR band patterns were calculated by using the area sensitive coefficient, taking into account the correspondence of bands expressed as the $S_{\mathrm{J}}$ coefficient, as well as the differences of the relative areas under each corresponding band (which is an indication of the DNA concentration of the corresponding band).

The relevance of various clustering algorithms was assessed on the basis of co-phenetic correlations comparing linkage distances with an input similarity matrix. The UPGMA algorithm showed the best co-phenetic correlations (95$98 \%$ ) and was, therefore, selected for constructing the dendrograms from the PFGE and ERIC-PCR data. The ribotype patterns were ordered by similarity matrix using the 
Euclidean model of multidimensional scaling. All statistical evaluations were made using statistical package SPSS 7.5 for Windows.

\section{RESULTS}

\section{Biotyping}

Nine $S$. carnosus and five $S$. piscifermentans strains were subjected to numerical analysis of 100 phenotypic features. All strains were positive for catalase, arginine dihydrolase, acid phosphatase, $\alpha$-glucosidase, esterase and esterase lipase, they reduced nitrate to nitrite, produced acid from D-glucose and D-fructose and grew at $15^{\circ} \mathrm{C}$. None of them produced acetoin, coagulase, lecithinase (egg-yolk reaction), acid from L- and D-arabinose, cellobiose, D-raffinose, erythritol, $\mathrm{L}$ - and $\mathrm{D}$-xylose, adonitol, methyl $\beta$-xyloside, sorbose, rhamnose, dulcitol, inositol, methyl $\alpha$-D-mannoside, methyl $\alpha$-D-glucoside, amygdalin, melibiose, inulin, amidon, arbutin, $\beta$-gentiobiose, glycogen, xylitol, D-lyxose, D-tagatose, L- and D-fucose, L- and D-arabitol, gluconate, or 2- and 5-ketogluconate. No hydrolysis of tyrosine, casein, starch, gelatin or elastin was observed. $\beta$-Glucuronidase, $\alpha$-galactosidase, $N$-acetyl- $\beta$-glucosaminidase, $\alpha$-mannosidase, $\alpha$-fucosidase, trypsin, chymotrypsin, arginine arylamidase, valine arylamidase and cystine arylamidase were negative in all strains. All strains exhibited the same antibiogram. They were resistant to tetracycline and oxacillin and were sensitive to gentamicin, imipenem, erythromycin, chloramphenicol, piperacillin, penicillin $\mathrm{G}$, novobiocin and nitrofurantoin. Variable reactions of both species are listed in Table 2.

In the dendrogram constructed from the $S_{J}$ values, the strains clustered into the following three separate phenons (Fig. 1): phenon $1\left(S_{\mathrm{J}}\right.$ values of $\left.70-100 \%\right)$, includes only the strains of $S$. carnosus clustered around their type strain DSM $20501^{\mathrm{T}}$; phenon $2\left(S_{\mathrm{J}}\right.$ values of $85-100 \%$ ), includes only the strains of $S$. piscifermentans clustered around their type strain CCM $4345^{\mathrm{T}}$; phenon 3 ( $S_{\mathrm{J}}$ values of $\left.78-100 \%\right)$, includes the strains $S$. carnosus SK 06 and $S$. piscifermentans SK 05 which did not cluster around any type strains mentioned above.

From data given in Table 2, it can be seen that phenon 1 (S. carnosus) and phenon 2 (S. piscifermentans) may be differentiated from each other based on the following phenotypic features: acid production from mannose, mannitol and sucrose, $\beta$-glucosidase, hydrolysis of aesculin, urease, hydrolysis of Tween 80 , pyrrolidonyl arylamidase and sensitivity to phages of the Twort species. Strain $S$. carnosus F-2 has several biochemical features (urease, hydrolysis of Tween 80 and pyrrolidonyl arylamidase) that are similar to those of S. piscifermentans. Phenon 3 is significantly different

\section{Table 2. Variable reactions of S. carnosus and S. piscifermentans}

Test: 1 , clumping factor; 2 , anaerobic growth in thioglycollate medium; 3 , growth at $45{ }^{\circ} \mathrm{C} ; 4$, growth in $15 \% \mathrm{NaCl}$;

5 , sensitivity to polyvalent bacteriophages of the species Twort; 6 , hydrolysis of DNA; 7 , hydrolysis of Tween $80 ; 8$, urease; 9, hydrolysis of aesculin; 10, acid from mannose; 11, acid from maltose; 12, acid from lactose; 13, acid from trehalose; 14, acid from mannitol; 15 , acid from ribose; $16, \beta$-galactosidase; 17 , pyrrolidonyl arylamidase; 18 , acid from sucrose; 19 , acid from $N$-acetylglucosamine; 20 , acid from turanose; 21 , acid from glycerol; 22 , acid from galactose; $23, \beta$-glucosidase; 24 , acid from melezitose; 25, acid from salicin; 26, acid from sorbitol; 27, alkaline phosphatase; 28, leucine arylamidase; 29 , naphthol AS-BI phosphohydrolase; + , positive reaction; $\mathrm{w}$, weak reaction; - , negative reaction.

\begin{tabular}{|c|c|c|c|c|c|c|c|c|c|c|c|c|c|c|c|c|c|c|c|c|c|c|c|c|c|c|c|c|c|}
\hline \multirow[t]{2}{*}{ Strain } & \multicolumn{29}{|c|}{ Test } \\
\hline & 1 & 2 & 3 & 4 & 5 & 6 & 7 & 8 & 9 & 10 & 11 & 12 & 13 & 14 & 15 & 16 & 17 & 18 & 19 & 20 & 21 & 22 & 23 & 24 & 25 & 26 & 27 & 28 & 29 \\
\hline \multicolumn{30}{|l|}{ S. carnosus } \\
\hline DSM $20501^{\mathrm{T}}$ & - & - & w & w & + & w & - & - & - & + & - & + & + & + & w & + & + & - & w & - & - & + & - & - & - & w & + & - & w \\
\hline CCM 3885 & - & - & + & + & + & w & - & - & - & + & - & + & + & + & w & + & + & - & w & - & - & + & - & - & - & w & + & w & w \\
\hline CCM 3886 & - & - & w & w & + & + & - & - & - & + & - & + & + & + & $\mathrm{w}$ & + & + & - & w & - & - & + & - & - & - & w & + & - & w \\
\hline CCM 4579 & - & - & - & + & + & + & - & - & - & + & - & + & + & + & w & + & + & - & w & - & - & + & - & - & - & w & + & - & w \\
\hline Mediph 2 & - & w & - & + & + & + & - & - & - & + & - & + & + & + & w & + & + & - & w & - & - & $\mathrm{w}$ & - & - & - & $\mathrm{w}$ & + & w & $\mathrm{w}$ \\
\hline M3 & - & - & - & + & + & $w$ & - & - & - & + & - & + & - & + & w & + & + & - & w & - & - & w & - & - & - & W & + & - & w \\
\hline TM300 & - & - & - & + & + & w & - & - & - & + & w & + & + & + & - & + & + & - & w & - & - & w & - & - & - & w & + & - & w \\
\hline SK 06 & - & w & - & - & - & - & - & - & - & - & - & - & + & - & - & - & - & - & - & - & - & - & - & - & - & - & - & - & + \\
\hline $\mathrm{F}-2$ & - & + & + & + & + & + & + & + & - & + & - & + & + & + & w & + & - & - & + & - & - & - & w & - & - & w & + & - & - \\
\hline \multicolumn{30}{|c|}{ S. piscifermentans } \\
\hline $\mathrm{CCM} 4345^{\mathrm{T}}$ & w & - & + & + & - & + & + & + & $\mathrm{w}$ & - & + & + & + & - & w & + & - & + & + & + & - & + & + & + & - & - & w & w & - \\
\hline CCM 4346 & w & + & + & w & - & + & + & + & + & - & + & + & + & - & w & + & - & + & + & + & - & + & + & + & - & - & $\mathrm{w}$ & w & - \\
\hline CCM 4347 & w & + & + & - & - & w & + & + & + & - & + & + & + & - & w & + & - & + & + & + & w & + & + & - & + & - & + & - & - \\
\hline SK 02 & - & + & + & w & - & + & + & + & + & - & - & + & + & - & - & + & - & w & + & - & - & + & + & + & + & - & + & w & - \\
\hline SK 05 & - & + & - & w & - & - & - & - & - & - & - & - & + & - & - & - & - & w & w & - & - & - & - & - & - & - & - & - & - \\
\hline
\end{tabular}




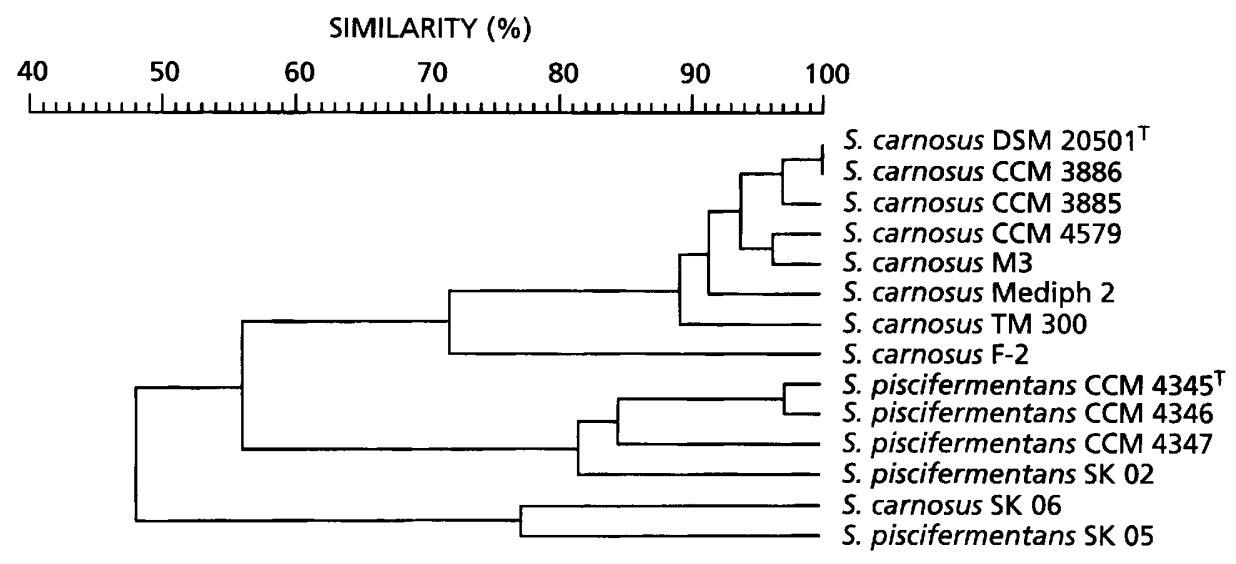

Fig. 1. Dendrogram based on the numerical analysis of 100 phenotypic traits. It shows the strains clustered into three phenons. The dendrogram was constructed by the UPGMA method with $S$, coefficients.

from both phenons 1 and 2 , being biochemically inactive in almost all features. Biochemical profiles from strains F-2, SK 05 and SK 06 exhibited low discrimination and they have not been precisely defined at the species level.

\section{Macrorestriction analysis using PFGE}

Genomic DNAs of all strains were cleaved by restriction endonucleases $S m a I$ and $A p a I$. In $S$. carnosus, SmaI cleaves the DNA into 17-23 restriction fragments $(3-910 \mathrm{~kb})$ and in $S$. piscifermentans, the DNA is cleaved into $26-27$ fragments $(4-750 \mathrm{~kb})$. Restriction endonuclease Apal cleaves the DNA of $S$. carnosus into $12-17$ fragments $(5-600 \mathrm{~kb})$ and that of $S$. piscifermentans into 19-24 fragments $(16-440 \mathrm{~kb})$. Seven $S$. carnosus strains maintain the same macrorestriction patterns when either SmaI or ApaI is used (Fig. 2a, b).

The similarity values ( $F_{x y}$ values) in macrorestriction patterns of different strains of $S$. carnosus and $S$. piscifermentans were used to group these strains into so-called species restriction groups. The species restriction group included the type strain and the strains resembling the type strain, in terms of the macrorestriction pattern of their genomes, within the range of similarity 25-100\% (Snopková et al., 1994). The similarity value of $25 \%$ was considered to be the lowest for defining the species restriction group, because the relationship between $F_{x y}$ and the amount of DNA sequence divergence is curvilinear, so that small errors at low values of $F_{x y}$ result in large errors in the estimation of DNA sequence divergence (Dowling et al., 1990). For this reason, it was suggested (Kessler \& Avise, 1985) that simple fragment comparison should not be used where less than $25 \%$ of the fragments are shared. The species restriction groups that were estimated by Snopková et al. (1994) are in good accordance with the results obtained by DNADNA hybridization studies of coagulase-negative staphylococci published previously (Schleifer \& Kroppenstedt, 1990; Kloos et al., 1992).

The dendrogram based on numerical analysis of $A p a I$ genomic macrorestriction patterns of $S$. carnosus and $S$. piscifermentans strains consists of two clusters. The clusters correspond to the species restriction groups $S$. carnosus and $S$. piscifermentans since each of them includes strains with macrorestriction patterns similar to that of their type strain. The level of similarity in the cluster of $S$. carnosus strains under study is $34 \%$, whereas for $S$. piscifermentans strains, the level is $54 \%$ (Fig. 2a).

The dendrogram based on SmaI genomic macrorestriction patterns (Fig. 2b) gives practically the same results as that based on ApaI. Two clusters, i.e. $S$. carnosus and S. piscifermentans, with their appropriate type strains were obtained, each being separated from the other on the level of $32 \%$ similarity. In both the dendrograms based on the ApaI and SmaI macrorestriction analysis, strain $S$. carnosus $\mathrm{F}-2$ occupied the marginal branch (at the level of $35 \%$ similarity).

On the whole, the $S$. carnosus and $S$. piscifermentans clusters based on the genomic macrorestriction patterns correspond to phenons 1 and 2 . Such a correspondence does not exist for strains SK 05 and SK 06. Even if these strains are phenotypically similar (phenon 3), they differ significantly from one another in their genomic DNA, SK 06 and SK 05 having macrorestriction patterns similar to those of the type strains $S$. carnosus DSM $20501^{\mathrm{T}}$ and $S$. piscifermentans CCM $4345^{\mathrm{T}}$, respectively.

\section{Ribotyping}

On the basis of EcoRI ribotype patterns (Fig. 2c), the strains $S$. carnosus and $S$. piscifermentans were divided into three clusters. The clusters were formed on the level of $65 \%$ similarity used by De Buyser et al. (1992) for separating different species of the genus Staphy- 


\section{SIMILARITY (\%)}

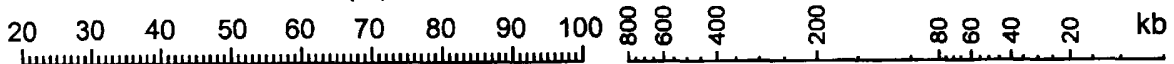

(a)

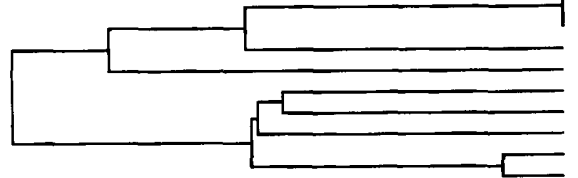
لسسسلسسسلسسسلسسسلسسسلسسسلسسس

(b)

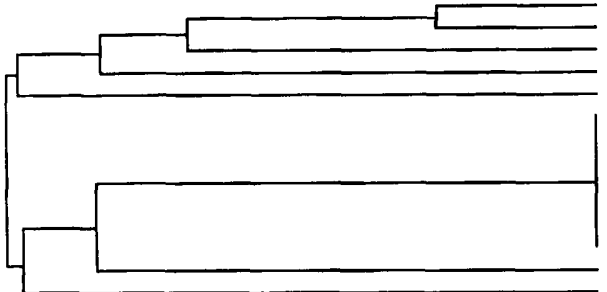

\section{$\begin{array}{cccccc}\text { SIMILARITY (\%) } \\ 40 \quad 50 & 60 & 70 & 80 & 90 & 100\end{array}$ \\ $\begin{array}{llllll}\text { SIMILARITY (\%) } \\ 40 \quad 50 & 60 & 70 & 80 & 90 & 100\end{array}$}

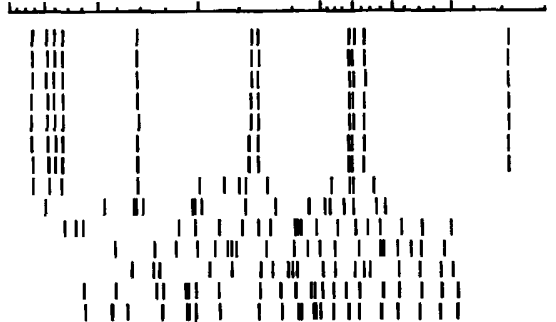

S. camosus DSM $20501^{\top}$

S. camosus CCM 3885

S. camosus CCM 3886

. camosus CCM 4579

. camosus Mediph 2

S. camosus TM 300

. camosus M3

camosus SK 06

camosus F-2

piscifermentans CCM 4347

piscifermentans SK 02

piscifermentans SK 05

S. piscifermentans CCM 4346

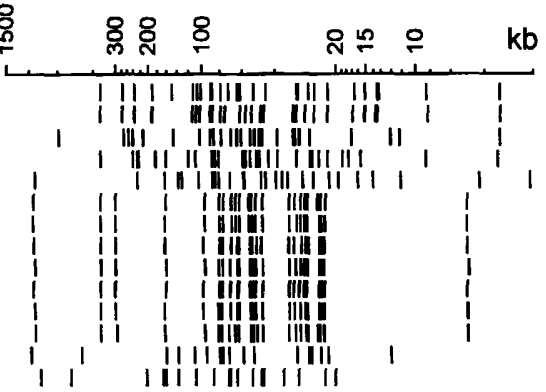

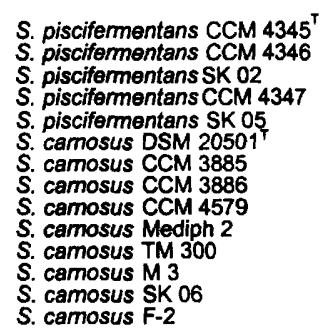

S. piscifermentans CCM 4345 . piscifermentans CCM 434 piscifermentans CCM 4347 carnosus DSM 20501 . camosus CCM 3885 camosus CCM 4579 camosus Mediph camosus $M 3$ camosus F-2

I I I III II ||

$$
\begin{aligned}
& 5^{2} \\
& { }^{\top} \\
& \\
& \\
& \\
& \\
& \\
&
\end{aligned}
$$

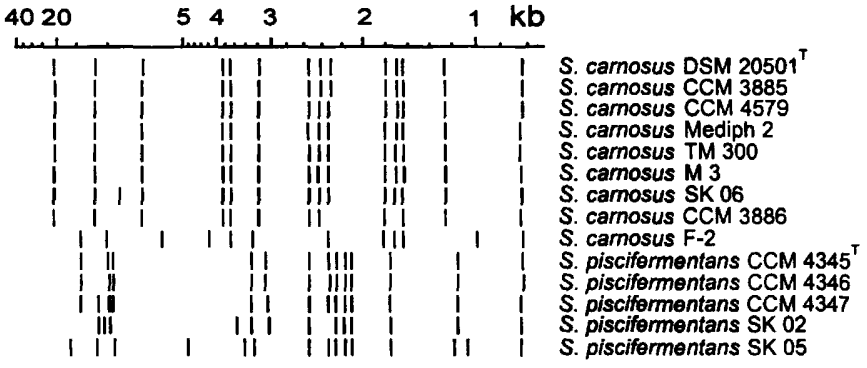

\section{SIMILARITY (\%)}

$\begin{array}{lllllllllll}0 & 10 & 20 & 30 & 40 & 50 & 60 & 70 & 80 & 90 & 100\end{array}$

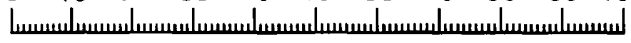

(d)

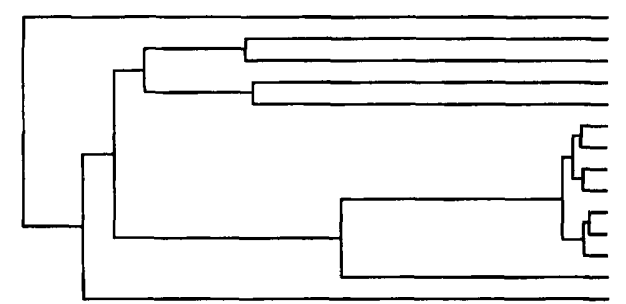

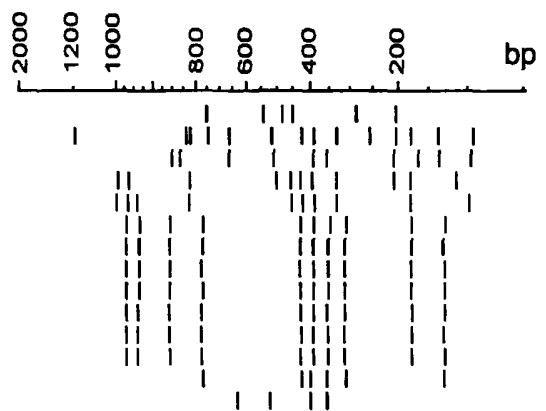

S. piscifermentans SK 05 S. piscifermentans CCM 4347 S. piscifiermentans SK $02{ }^{2} 7^{\top}$ S. piscifermentans CCM 4346 S. camosus DSM $20501^{\top}$ S. camosus CCM 3885 S. camosus CCM 3886 . camosus Mediph 2 S. camosus $\mathrm{M} 3 \mathrm{M}$ S. camosus M $\mathrm{M} 300$ S. camosus TM 300 S. camosus F-2

Fig. 2. Cluster analysis of gel images, which were digitized by scanning procedures. Schematic representation of band patterns for each of the DNA fingerprinting techniques and size of DNA fragments expressed in kbp or bp respectively, are given. The dendrograms were constructed by the UPGMA method. (a) Dendrogram showing the degree of similarity of Apal macrorestriction patterns of the genomic DNAs. (b) Dendrogram showing the degree of similarity of Smal macrorestriction patterns of the genomic DNAs. (c) Three-dimensional ordination plot showing the clustering of EcoRI ribotype patterns on the basis of their similarity coefficients $F_{x y}$. (d) Dendrogram showing the degree of similarity of PCR fingerprints as generated by amplification of genomic DNA by primers ERIC $1 R$ and ERIC 2 derived from enterobacterial repetitive intergenic consensus sequences. 
lococcus. The results are as follows: cluster 1, including the same strains of $S$. carnosus as shown in macrorestriction analysis (Fig. 2a, b) except for strain F-2 (strains DSM 20501 ${ }^{\mathrm{T}}$, CCM 3885, CCM 4579, Mediph 2, TM 300 and M3 are identical on the basis of ribotyping and the similarity of strains belonging to this species was higher than $90 \%$ ); cluster 2 , including the same strains of $S$. piscifermentans as shown in macrorestriction analysis (Fig. 2a, b) [the ribotype patterns of $S$. piscifermentans are more heterogeneous ( $72 \%$ similarity) than those of $S$. carnosus and only two ribotypes are the same (CCM $4345^{\mathrm{T}}$ and CCM 4346)]; and cluster 3 , represented only by strain F-2 and separated from the other $S$. carnosus strains at the level of $52 \%$ similarity. The strain has some EcoRI ribotype motifs in common with $S$. piscifermentans (3.2, 10 and $14 \mathrm{~kb}$ fragments).

\section{ERIC-PCR typing}

The highest discrimination ability and reproducibility of PCR was reached when primers ERIC $1 R$ and ERIC 2 were both used. From the dendrogram (Fig. 2d), it follows that eight strains of $S$. carnosus formed one cluster on the level of $56 \%$ similarity. On the other hand, strains of $S$. piscifermentans formed a heterogeneous cluster on the level of $24 \%$ similarity. Strain F-2 formed a separate cluster on the level of $13 \%$ similarity. A separate cluster on the level of $5 \%$ similarity was also formed by strain SK 05 .

\section{DISCUSSION}

DNA analysis was shown to be an important and useful tool in molecular taxonomy. In staphylococci, it started with differentiation on the basis of DNA base composition of the family Micrococcaceae in two genetically distant genera Micrococcus and Staphylococcus (Silvestri \& Hill, 1965; Rosypal et al., 1966). Nucleic acid hybridization studies have resulted in a marked revision of the genus Staphylococcus and in the description of new species (Schleifer \& Kroppenstedt, 1990; Kloos et al., 1992). In recent years, different DNA fingerprinting techniques, which provide indirect access to DNA sequence polymorphisms, have also been used in the study of the staphylococcal genome (Tenover et al., 1994; Kloos \& Bannerman, 1995). The importance of DNA fingerprinting by PFGE as a tool for the differentiation of coagulasenegative staphylococci was emphasized by Lina et al. (1992), Linhardt et al. (1992), Snopková et al. (1994) and George \& Kloos (1994). Moschetti et al. (1997) used PFGE of SmaI macrorestriction fragments to analyse strains of $S$. xylosus isolated from fermented sausages. Ribotyping, a method based on rRNA gene restriction site polymorphism, was developed for differentiation of Staphylococcus species and subspecies (El Solh et al., 1990; De Buyser et al., 1989, 1992). It was used for distinguishing a newly described Staphylococcus species and subspecies from previously described taxa (Chesneau et al., 1993; Webster et al.,
1994; Kloos et al., 1997), for the routine identification of isolates (Chesneau et al., 1992) and for detecting intraspecies differences (Hesselbarth \& Schwarz, 1995; Grattard et al., 1993; Meugnier et al., 1993). Another approach for intraspecies strain fingerprinting is ERIC-PCR (Versalovic et al., 1991; Lupski \& Weinstock, 1992). This method was suitable for discriminating strains of a variety of Eubacteria including Staphylococcus aureus (Struelens et al., 1993; van Belkum et al., 1994, 1995; van Leeuwen et al., 1996).

Typing systems based solely on phenotypic tests have limitations because phenotypic traits are inconsistently expressed (Popovic et al., 1993) or some species can be distinguished by only a limited number of stable biochemical tests (Chesneau et al., 1992). Additionally, in a few cases our results did not correspond with the species description or data from references (Schleifer \& Fischer, 1982; Tanasupawat et al., 1991; Holt et al., 1994), e.g. acid from glycerol, mannose, lactose and trehalose and $\beta$-galactosidase, $\alpha$-glucosidase and acetoin production were not uniform (Table 2).

In this paper, we have used the fingerprinting methods in conjunction with numerical analysis of 100 phenotypic traits of the species $S$. carnosus and $S$. piscifermentans. The results we obtained lead to the conclusion that strains $S$. carnosus and $S$. piscifermentans form two separate phenons (except for strains $S$. carnosus SK 06 and S. piscifermentans SK $05)$ corresponding with clusters formed on the basis of different DNA fingerprinting techniques. The two clusters, each involving strains that are similar both in their phenotypic traits and their genomic DNA, correspond with the definition of the species $S$. carnosus proposed by Schleifer \& Fischer (1982) and $S$. piscifermentans proposed by Tanasupawat et al. (1992). The results of DNA fingerprinting methods reported in our paper are also in accordance with DNA hybridization of the same strains made by Tanasupawat et al. (1991, 1992).

Strains SK 06 and SK 05 are evidently phenotypically convergent, since genomic analysis used in our paper unambiguously showed that the genome of SK 06 is similar to that of the type strain $S$. carnosus DSM $20501^{\mathrm{T}}$ and that of SK 05 is similar to that of the type strain $S$. piscifermentans $\mathrm{CCM} 4345^{\mathrm{T}}$. As reported by Tanasupawat et al. (1991), the genome homology estimated by hybridization of DNA of strain SK 06 with DNA of the type strain of S. carnosus was $100 \%$. On the other hand, the genome homology estimated by hybridization of the DNA of strain SK 05 with DNA of the type strain of $S$. piscifermentans was $80 \%$. Thus, the classification of these strains in a separate species based only on their mutual phenotypic similarity would be misleading. On the basis of their physiological properties as well as on the basis of reaction with specific $23 \mathrm{~S}$ rRNA-directed probes, Probst et al. (1998) placed strain SK 06 in a new subspecies of $S$. carnosus (Schleifer \& Fischer, 1982). They designated 
the new subspecies $S$. carnosus subsp. utilis (Probst et al., 1998). Our results support this classification.

The results obtained by the use of different DNA fingerprinting methods indicate collectively that the genome of strain F-2 is not similar to that of the type strain of S. piscifermentans. On the other hand, this strain exhibits genomic similarity to the type strain of $S$. carnosus, even if this similarity is significantly lower in comparison with that of the other strains of $S$. carnosus. Its separate position in the group of $S$. carnosus strains is supported by the following facts. (i) The similarity coefficient in phenotypic features of strain $\mathrm{F}-2$ in relation to the type strain $S$. carnosus DSM $20501^{\mathrm{T}}$ is as high as $70 \%$. In spite of the fact that it has some phenotypic characteristics common to the other strains of $S$. carnosus, classification with this species made solely on the basis of determinative traits has not been successful. (ii) Tanasupawat et al. (1991) estimated the DNA homology of strain F-2 with the type strain of $S$. carnosus to be $69 \%$ and with that of $S$. piscifermentans $48 \%$. On the other hand, Probst et al. (1998) estimated that the DNA homology of strain F-2 is $58 \%$ with the S. carnosus type strain and $51 \%$ with the $S$. piscifermentans type strain. According to the phylogenetic definition of a species proposed by Wayne et al. (1987), the species generally should include strains with approximately $70 \%$ or greater DNA-DNA relatedness. (iii) The similarity of the F-2 genome in relation to the genome of the type strain $S$. carnosus DSM $20501^{\mathrm{T}}$, based on SmaI and ApaI macrorestriction patterns, is $32 \%$, i.e. near the lowest value $(25 \%)$ of similarity in the macrorestriction patterns recommended by Snopková et al. (1994) and Pantůček et al. (1996) for the species restriction group. (iv) The similarity coefficient in terms of the EcoRI ribotype of strain F-2 in relation to the type strain DSM $20501^{\mathbf{T}}\left(F_{x y}=53.8 \%\right)$ is lower than the lowest intra-taxon value $(65 \%)$ proposed by De Buyser et al. (1992) in their identification scheme. (v) Additionally, the results obtained by ERIC-PCR indicate a very low similarity between F-2 and all strains of $S$. carnosus.

From our results and also from those reported by Probst et al. (1998), it follows that strain F-2 is phenotypically and genetically the most distant from the type strain $S$. carnosus DSM $20501^{\mathrm{T}}$ of all the $S$. carnosus strains under study. This is in accordance with the proposal reported by Probst et al. (1998) that this strain should be classified as a new species, $S$. condimenti.

On the whole, it can be said that the strains under study, with the exception of strain F-2, grouped together with their type strains into clusters, the composition of which was shown to be stable even if different DNA fingerprinting techniques were used. It can be expected that the restriction map constructed by Wagner et al. (1998) will also completely hold for the strains $S$. carnosus DSM $20501^{\mathrm{T}}$, CCM 3885, CCM 3886, CCM 4579, Mediph 2 and M3, which all have $100 \%$ similarity to $S$. carnosus TM 300 .

\section{ACKNOWLEDGEMENTS}

This work was supported by the European Community (contract no. CIPA CT 9300145) and by the Grant Agency of the Czech Republic (301/97/1192).

\section{REFERENCES}

Augustin, J. \& Götz, F. (1990). Transformation of Staphylococcus epidermidis and other staphylococcal species with plasmid DNA by electroporation. FEMS Microbiol Lett 66, 203-208.

Augustin, J., Rosenstein, R., Wieland, B., Schneider, U., Schnell, N., Engelke, G., Entian, K.-D. \& Gobtz, F. (1992). Genetic analysis of epidermin biosynthetic genes and epidermin-negative mutants of Staphylococcus epidermidis. Eur $J$ Biochem 204, 1149-1154.

Ayora, S. \& Götz, F. (1994). Genetic and biochemical properties of an extracellular neutral metalloprotease from Staphylococcus hyicus subsp. hyicus. Mol Gen Genet 242, 421-430.

Bangsborg, J. M., Gerner-Smidt, P., Colding, H., Fiehn, N.-E., Bruun, B. \& Hoiby, N. (1995). Restriction fragment length polymorphism of rRNA genes for molecular typing of the family Legionellaceae. J Clin Microbiol 33, 402-406.

Barrow, G. I. \& Feltham, R. K. A. (editors) (1993). Cowan and Steel's Manual for the Identification of Medical Bacteria, 3rd edn. Cambridge: Cambridge University Press.

van Belkum, A., Bax, R., van der Straaten, P. J. C., Quint, W. G. V. \& Veringa, E. (1994). PCR fingerprinting for epidemiological studies of Staphylococcus aureus. J Microbiol Methods 20, 235-247.

van Belkum, A., Kluytmans, J., van Leeuwen, W. \& 16 other authors (1995). Multicentre evaluation of arbitrarily primed PCR for typing of Staphylococcus aureus strains. J Clin Microbiol 33, 1537-1547.

Brückner, R. (1997). Gene replacement in Staphylococcus carnosus and Staphylococcus xylosus. FEMS Microbiol Lett 151, 1-8.

Brückner, R. \& Götz, F. (1996). Development of a food-grade vector system for Staphylococcus carnosus. Syst Appl Microbiol 18, 510-516.

Chesneau, O., Aubert, S., Morvan, A., Guesdon, J. L. \& El Solh, N. (1992). Usefulness of the ID32 Staph system and a method based on rRNA gene restriction site polymorphism analysis for species and subspecies identification of staphylococcal clinical isolates. J Clin Microbiol 30, 2346-2352.

Chesneau, O., Morvan, A., Grimont, F., Labischinski, H. \& El Solh, N. (1993). Staphylococcus pasteuri sp. nov., isolated from human, animal, and food specimens. Int $J$ Syst Bacteriol 43, 237-244.

Christiansen, I. \& Hengstenberg, W. (1996). Cloning and sequencing of two genes from Staphylococcus carnosus encoding glucose-specific PTS and their expression in Escherichia coli K12. Mol Gen Genet 250, 375-379.

Connolly, S., Phillips, I. \& Noble, W. C. (1994). Cloning and expression of the mupirocin resistance gene in Staphylococcus carnosus. Med Microbiol Lett 3, 409-415.

De Buyser, M. L., Morvan, A., Grimont, F. \& El Solh, N. (1989). Characterization of Staphylococcus species by rRNA gene restriction patterns. J Gen Microbiol 135, 989-999.

De Buyser, M. L., Morvan, A., Aubert, S., Dilasser, F. \& El Solh, N. (1992). Evaluation of a rRNA gene probe for the identification of species and subspecies within the genus Staphylococcus. J Gen Microbiol 138, 889-899. 
Demleitner, G. \& Götz, F. (1994). Evidence for importance of the Staphylococcus hyicus lipase pro-peptide in lipase secretion, stability and activity. FEMS Microbiol Lett 121, 189-197.

Dowling, T. E., Moritz, C. \& Palmer, J. D. (1990). Nucleic acids II : restriction site analysis. In Molecular Systematics, pp. 250-315. Edited by D. M. Hillis \& C. Moritz. Sunderland, MA: Sinauer.

El Solh, N., De Buyser, M. L., Morvan, A., Grimont, F., SalesseWalcher, S., Aubert, S., Monzon-Monreo, C., Chesneau, 0. \& Allignet, J. (1990). Use of Bacillus subtilis 16S rRNA genes as a probe to identify species, subspecies and types in the genus Staphylococcus. In Molecular Biology of the Staphylococci, pp. 585-593. Edited by R. P. Novick. New York: VCH.

Fast, B., Lindgren, P. E. \& Götz, F. (1996). Cloning, sequencing, and characterization of a gene (narT) encoding a transport protein involved in dissimilatory nitrate reduction in Staphylococcus carnosus. Arch Microbiol 166, 361-367.

Fischer, U. \& Schleifer, K. H. (1980). Zum Vorkommen der Grampositiven, katalase-positiven Kokken in Rohwurst. Fleischwirtschaft 60, 1046-1051.

George, C. G. \& Kloos, W. E. (1994). Comparison of the SmaIdigested chromosomes of Staphylococcus epidermidis and the closely related species Staphylococcus capitis and Staphylococcus caprae. Int J Syst Bacteriol 44, 404409.

Götz, F. (1990). Staphylococcus carnosus: a new host organism for gene cloning and protein production. J Appl Bacteriol (Symp Suppl) 49S-53S.

Götz, F. \& Schumacher, B. (1987). Improvements of protoplast transformation in Staphylococcus carnosus. FEMS Microbiol Lett 40, 285-288.

Götz, F., Kreutz, B. \& Schleifer, K. H. (1983). Protoplast transformation of Staphylococcus carnosus by plasmid DNA. Mol Gen Genet 189, 340-342.

Grattard, F., Etienne, J., Pozzetto, B., Tardy, F., Gaudin, O. G. \& Fleurette, J. (1993). Characterization of unrelated strains of Staphylococcus schleiferi by using rDNA fingerprinting, DNA restriction patterns, and plasmid profiles. J Clin Microbiol 31, $812-818$.

Halfmann, G., Götz, F. \& Lubitz, W. (1993). Expression of bacteriophage $\phi$ X174 lysis gene-E in Staphylococcus carnosus TM300. FEMS Microbiol Lett 108, 139-144.

Hammes, W. P., Bosch, I. \& Wolf, G. (1995). Contribution of Staphylococcus carnosus and Staphylococcus piscifermentans to the fermentation of protein foods. $J$ Appl Bacteriol (Symp Suppl) 76S-83S.

Hartmann, S., Wolf, G. \& Hammes, W. P. (1995). Reduction of nitrite by Staphylococcus carnosus and Staphylococcus piscifermentans. Syst Appl Microbiol 18, 323-328.

Hébert, G. A., Crowder, C. G., Hancock, G. A., Jarvis, W. R. \& Thornsberry, C. (1988). Characteristics of coagulase-negative staphylococci that help differentiate these species and other members of the family Micrococcaceae. J Clin Microbiol 26, 1939-1949.

Heilmann, C., Schweitzer, O., Gerke, C., Vanittanakom, N., Mack, D. \& Götz, F. (1996). Molecular basis of intercellular adhesion in the biofilm-forming Staphylococcus epidermidis. Mol Microbiol 20, 1083-1091.

Hesselbarth, J. \& Schwarz, S. (1995). Comparative ribotyping of Staphylococcus intermedius from dogs, pigeons, horses and mink. Vet Microbiol 45, 11-17.

Holt, J. G., Krieg, N. R., Sneath, P. H. A., Staley, J. T. \& Williams, S. T. (1994). Bergey's Manual of Determinative Bacteriology, 9th edn. Baltimore: Williams \& Wilkins.
Keller, G., Schleifer, K. H. \& Götz, F. (1983). Construction and characterization of plasmid vectors for cloning in Staphylococcus aureus and Staphylococcus carnosus. Plasmid 10, 270-278.

Kessler, L. G. \& Avise, J. C. (1985). A comparative description of mitochondrial differentiation in selected avian and other vertebrate genera. Mol Biol Evol 2, 109-126.

Kloos, W. E. \& Schleifer, K. H. (1975). Simplified scheme for routine identification of human Staphylococcus species. J Clin Microbiol 1, 82-88.

Kloos, W. E. \& Bannerman, T. (1994). Update on clinical significance of coagulase-negative staphylococci. Clin Microbiol $\operatorname{Rev} 7,117-140$

Kloos, W. E. \& Bannerman, T. (1995). Staphylococcus and Micrococcus. In Manual of Clinical Microbiology, 6th edn, pp. 282-298. Edited by P. R. Murray, E. J. Baron, M. A. Pfaller, F. C. Tenover \& R. H. Yolken. Washington, DC: American Society for Microbiology.

Kloos, W. E., Schleifer, K. H. \& Götz, F. (1992). The genus Staphylococcus. In The Prokaryotes, 2nd edn, pp. 1369-1420. Edited by A. Balows, H. G. Trüper, M. Dworkin, W. Harder \& K.-H. Schleifer. New York: Springer.

Kloos, W. E., Ballard, D. N., Webster, J. A. \& 12 other authors (1997). Ribotype delineation and description of Staphylococcus sciuri subspecies and their potential as reservoirs of methicillin resistance and staphylolytic enzyme genes. Int $J$ Syst Bacteriol 47, 313-323.

Kohlbrecher, D., Eisermann, R. \& Hengstenberg, W. (1992). Staphylococcal phosphoenolpyruvate-dependent phosphotransferase system: molecular cloning and nucleotide sequence of the Staphylococcus carnosus ptsI gene and expression and complementation studies of the gene product. $J$ Bacteriol 174 , 2208-2214.

Kreutz, B. \& Götz, F. (1984). Construction of Staphylococcus plasmid vector pCA43 conferring resistance to chloramphenicol, arsenate, arsenite and antimony. Gene 32, 301-304.

van Leeuwen, W., Sijmons, M., Sluijs, J., Verbrugh, H. \& van Belkum, A. (1996). On the nature and use of randomly amplified DNA from Staphylococcus aureus. J Clin Microbiol 34, 2770-2777.

Liljeqvist, S., Samuelson, P., Hansson, M., Nguyen, T. N., Binz, H. \& Stăhl, S. (1997). Surface display of the cholera toxin B subunit on Staphylococcus xylosus and Staphylococcus carnosus. Appl Environ Microbiol 63, 2481-2488.

Lina, B., Vandenesch, F., Etienne, J., Kreiswirth, B. \& Fleurette, J. (1992). Comparison of coagulase-negative staphylococci by pulsed-field gel electrophoresis. FEMS Microbiol Lett 92, 133-138.

Linhardt, F., Ziebuhr, W., Meyer, P., Witte, W. \& Hacker, J. (1992). Pulsed-field gel electrophoresis of genomic restriction fragments as a tool for the epidemiological analysis of Staphylococcus aureus and coagulase-negative staphylococci. FEMS Microbiol Lett 95, 181-186.

Logan, N. A. (1994). Bacterial Systematics. Oxford: Blackwell. Lupski, J. R. \& Weinstock, G. M. (1992). Short, interspersed repetitive DNA sequences in prokaryotic genomes. $J$ Bacteriol 174, 4525-4529.

Maniatis, T., Fritsch, E. F. \& Sambrook, J. (1982). Molecular Cloning : a Laboratory Manual. Cold Spring Harbor, NY: Cold Spring Harbor Laboratory.

Meens, J., Klose, R. \& Freudel, R. (1994). The Staphylococcus carnosus sec E gene: cloning, nucleotide sequence and functional 
characterization in Escherichia coli secE mutant strain. FEMS Microbiol Lett 117, 113-120.

Meugnier, H., Fernandez, M. P., Bes, M., Brun, Y., Bornstein, N., Freney, J. \& Fleurette, J. (1993). rRNA gene restriction patterns as an epidemiological marker in nosocomial outbreaks of Staphylococcus aureus infections. Res Microbiol 144, 25-33.

Moschetti, G., Mauriello, G. \& Villani, F. (1997). Differentiation of Staphylococcus xylosus strains from Italian sausages by antibiotyping and low frequency restriction fragment analysis of genomic DNA. Syst Appl Microbiol 20, 432-438.

Nei, M. \& Li, W.-H. (1979). Mathematical model for studying genetic variation in terms of restriction endonucleases. Proc Natl Acad Sci USA 76, 5269-5273.

Neubauer, H. \& Götz, F. (1996). Physiology and interaction of nitrate and nitrite reduction in Staphylococcus carnosus. $J$ Bacteriol 178, 2005-2009.

Niinivaara, F. P. \& Pohja, M. S. (1956). Über die Reifung der Rohwurst. I. Mitt: Die Veränderung der Bakterienflora während der Reifung. Z Lebensm-Unters-Forsch 104, 413-422.

Nychas, G. J. \& Arkoudelos, J. S. (1990). Staphylococci: their role in fermented sausages. J Appl Bacteriol (Symp Suppl) 167S$188 \mathrm{~S}$.

Pantůček, R., Götz, F., Doškař, J. \& Rosypal, S. (1996). Genomic variability of Staphylococcus aureus and the other coagulasepositive Staphylococcus species estimated by macrorestriction analysis using pulsed-field gel electrophoresis. Int $J$ Syst Bacteriol 46, 216-222.

Pantůček, R., Rosypalová, A., Doškař, J., Kailerová, J., Růžičková, V., Borecká, P., Snopková, S.., Horváth, R., Götz, F. \& Rosypal, S. (1998). The polyvalent staphylococcal phage $\phi 812$ : its hostrange mutants and related phages. Virology 246, 241-252.

Popovic, T., Bopp, Ch. A., Orjan, O. \& Kiehlbauch, J. A. (1993). Ribotyping in molecular epidemiology. In Diagnostic Molecular Microbiology. Principles and Applications, pp. 573-583. Edited by D. H. Persing, T. F. Smith, F. C. Tenover \& T. J. White. Washington, DC: American Society for Microbiology.

Probst, A. J., Hertel, C., Richter, L., Wassill, L., Ludwig, W. \& Hammes, W. P. (1998). Staphylococcus condimenti sp. nov., from soy sauce mash, and Staphylococcus carnosus (Schleifer and Fischer 1982) subsp. utilis subsp. nov. Int $J$ Syst Bacteriol 48, 651-658.

Pschorr, J., Bieseler, B. \& Fritz, H. J. (1994). Production of the immunoglobulin variable domain REI(V) via a fusion protein synthesized and secreted by Staphylococcus carnosus. Biol Chem Hoppe-Seyler 375, 271-280.

Robert, A., Samuelson, P., Andréoni, C., Bächi, T., Uhlén, M., Binz, H., Nguyen, T. N. \& Stăhl, S. (1996). Surface display on staphylococci: a comparative study. FEBS Lett 390, 327-333.

Rosenstein, R., Peschel, A., Wieland, B. \& Götz, F. (1992). Expression and regulation of the antimonite, arsenite, and arsenate resistance operon of Staphylococcus xylosus plasmid pSX267. J Bacteriol 174, 3676-3683.

Rosypal, S., Rosypalová, A. \& Hoł̌eǰ̌, J. (1966). The classification of micrococci and staphylococci based on their DNA base composition and Adansonian analysis. J Gen Microbiol 44, 281-292.

Samuelson, P., Hansson, M., Ahlborg, N., Andréoni, C., Götz, F., Bächi, T., Nguyen, T. N., Binz, H., Uhlén, M. \& Ståhl, S. (1995). Cell surface display of recombinant proteins on Staphylococcus carnosus. J Bacteriol 177, 1470-1476.

Schleifer, K. H. \& Fischer, U. (1982). Description of a new species of the genus Staphylococcus: Staphylococcus carnosus. Int J Syst Bacteriol 32, 153-156.

Schleifer, K. H. \& Kroppenstedt, R. M. (1990). Chemical and molecular classification of staphylococci. J Appl Bacteriol (Symp Suppl) 9S-24S

Silvestri, L. G. \& Hill, L. R. (1965). Agreement between deoxyribonucleic acid base composition and taxometric classification of Gram-positive cocci. J Bacteriol 90, 136-140.

Sneath, P. H. A. \& Sokal, R. R. (1973). Numerical Taxonomy. The Principles and Practice of Numerical Classification. San Francisco: Freeman.

Snopková, ড̌., Götz, F., Doškar̆, J. \& Rosypal, S. (1994). Pulsed field gel electrophoresis of the genomic restriction fragments of coagulase-negative staphylococci. FEMS Microbiol Lett 124, 131-140.

Strauss, A. \& Gotz, F. (1996). In vivo immobilization of enzymically active polypeptides on the cell surface of Staphylococcus carnosus. Mol Microbiol 21, 491-500.

Struelens, M. J., Bax, R., Deplano, A., Quint, W. G. V. \& van Belkum, A. (1993). Concordant clonal delineation of methicillinresistant Staphylococcus aureus by macrorestriction analysis and polymerase chain reaction genome fingerprinting. $J$ Clin Microbiol 31, 1964-1970.

Tanasupawat, S., Hashimoto, Y., Ezaki, T., Kozaki, M. \& Komagata, K. (1991). Identification of Staphylococcus carnosus strains from fermented fish and soy sauce mash. J Gen Appl Microbiol 37, 479-494.

Tanasupawat, S., Hashimoto, Y., Ezaki, T., Kozaki, M. \& Komagata, K. (1992). Staphylococcus piscifermentans sp. nov., from fermented fish in Thailand. Int $J$ Syst Bacteriol 42, 577-581.

Tenover, F. C., Arbeit, R., Archer, G. \& 15 other authors (1994). Comparison of traditional and molecular methods of typing isolates of Staphylococcus aureus. J Clin Microbiol 32, 407-415.

Thumm, G. \& Götz, F. (1997). Studies on prolysostaphin processing and characterization of the lysostaphin immunity factor (Lif) of Staphylococcus simulans biovar staphylolyticus. Mol Microbiol 23, 1251-1265.

Upholt, W. B. (1977). Estimation of DNA sequence divergence from comparison of restriction endonuclease digests. Nucleic Acids Res 4, 1257-1265.

Versalovic, J., Koeuth, T. \& Lupski, J. R. (1991). Distribution of repetitive DNA sequences in eubacteria and application to fingerprinting of bacterial genomes. Nucleic Acids Res 19, 6823-6831.

Wagner, E., Doškař, J. \& Götz, F. (1998). Physical and genetic map of the genome of Staphylococcus carnosus TM300. Microbiology 144, 509-517.

Wayne, L. G., Brenner, D. J., Colwell, R. R. \& 9 other authors (1987). International Committee on Systematic Bacteriology. Report of the ad hoc committee on reconciliation of approaches to bacterial systematics. Int J Syst Bacteriol 37, 463-464.

Webster, J. A., Bannerman, T. L., Hubner, R. J., Ballard, D. N. Cole, E. M., Bruce, J. L., Fiedler, F., Schubert, K. \& Kloos, W. E. (1994). Identification of the Staphylococcus sciuri species group with EcoRI fragments containing rRNA sequences and description of Staphylococcus vitulus sp. nov. Int J Syst Bacteriol 44, 454-460.

Wieland, B., Feil, C., Gloria-Maercker, E., Thumm, G., Lechner, M., Bravo, J.-M., Poralla, K. \& Götz, F. (1994). Genetic and bio- 
chemical analyses of the biosynthesis of the yellow carotenoid 4,4'-diaponeurosporene of Staphylococcus aureus. J Bacteriol 176, 7719-7726.

Wieland, K.-P., Wieland, B. \& Götz, F. (1995). A promoterscreening plasmid and xylose-inducible, glucose-repressible expression vectors for Staphylococcus carnosus. Gene 158, 91-96.
Witke, C. \& Götz, F. (1993). Cloning, sequencing, and characterization of the gene encoding the class-I fructose-1,6bisphosphate aldolase of Staphylococcus carnosus. J Bacteriol 175, 7495-7499.

Witke, C. \& Götz, F. (1995). Cloning and nucleotide sequence of the signal peptidase II (lsp)-gene from Staphylococcus carnosus. FEMS Microbiol Lett 126, 233-239. 